\title{
PROSES KONTRUKSI PENGETAHUAN SISWA DITINJAU DARI GAYA KOGNITIF FIELD DEPENDENT PADA PELAJARAN MATEMATIKA DI SMA NEGERI 8 KOTA JAMBI
}

\author{
Sri Dewi ${ }^{1}$ \\ Dosen Program Studi Pendidikan Matematika, FKIP, Universitas Batanghari Jambi ${ }^{1}$ \\ E-mail: dedewsri1982@gmail.com
}

\begin{abstract}
ABSTRAK
Setiap siswa memiliki kekhasan karakter tersendiri dengan kemampuan dan cara belajarnya yang berbeda dengan siswa lainnya dalam memproses dan menyusun pengetahuannya. Dalam menyusun pengetahuan, siswa yang memiliki gaya kognitif field dependent memproses informasi dari lingkungannya, kemudian merepresentasikannya di dalam pikirannya sehingga menjadi bentuk skema-skema yang bermakna. Penelitian ini bertujuan untuk mendeskripsikan proses konstruksi pengetahuan siswa ditinjau dari gaya kognitif field dependent dalam memahami materi trigonometri pada mata pelajaran matematika di SMA Negeri 8 Kota Jambi. Jenis penelitian yang digunakan adalah kualitatif yang menggunakan metodologi penelitian kualitatif deskriptif. Subjek penelitian adalah siswa kelas $\mathrm{X}$ yang memiliki gaya kognitif field dependent yang didasarkan pada hasil tes penentuan gaya kognitif. Teknik pemilihan subjek penelitian yang digunakan adalah teknik snowball sampling. Hasil penelitian menunjukkan bahwa semua proses konstruksi pengetahuan yang dibentuk oleh SA dan SB dimulai dari informasi yang dibaca melalui lembar pencerap informasi yang datang sesuai dengan skema yang dimiliki oleh SA dan SB yang kemudian digunakan untuk membentuk konstruksi pengetahuan selanjutnya yang sesuai dengan langkah-langkah Taksonomi Bloom
\end{abstract}

Kata Kunci:

Gaya Kognitif Field Dependent; Kontruksi Pengetahuan.

\begin{abstract}
Each student has their own unique character with different abilities and ways of learning with other students in processing and organizing their knowledge. In compiling knowledge, students who have a field dependent cognitive style process information from their environment, then represent it in their minds to form meaningful schemes. This study aims to describe the process of constructing students' knowledge in terms of the field dependent cognitive style in understanding trigonometric material in mathematics in SMA Negeri 8 Jambi City. This type of research is qualitative which uses descriptive qualitative research methodology. The subjects were grade $X$ students who had field dependent cognitive styles based on the results of cognitive style determination tests. The research subject selection technique used was snowball sampling technique. The results showed that all knowledge construction processes formed by SA and SB were started from information read through the information absorbing sheets that came in accordance with the schemes owned by $S A$ and $S B$ which were then used to form the next knowledge construction in accordance with Bloom's Taxonomic steps.
\end{abstract}

Keywords:

Field Dependent Cognitive Style; Knowledge Construction.

\section{PENDAHULUAN}

Setiap individu memiliki karakteristik khas yang tidak dimiliki oleh individu lain. Oleh karena itu, dapat dikatakan bahwa setiap individu berbeda dengan yang lainnya. Salah satu tinjauan perbedaan ini adalah dari aspekaspek perseptual dan intelektual. Aspek perseptual dan intelektual mengungkapkan bahwa setiap individu mempunyai ciri khas yang berbeda dengan individu lain. Sesuai dengan tinjauan aspek perseptual dan intelektual tersebut, dikemukakan bahwa perbedaan individu dapat diungkapkan oleh tipe-tipe kognitif yang dikenal dengan gaya kognitif. Menurut Desmita (2012:145) gaya kognitif adalah karakteristik individu dalam penggunaan fungsi kognitif (berfikir, mengingat,

Sri Dewi

Proses Konstruksi Pengetahuan Siswa Ditinjau dari Gaya Kognitif Field Dependent pada Pelajaran Matematika Di SMA Negeri 8 Kota Jambi 


\section{$\pi$ (Phi)}

memecahkan masalah, membuat keputusan. Pendapat serupa juga disampaikan Kagan (Susanto, 2015), bahwa gaya kognitif yaitu sebagai variasi cara individu dalam menerima, mengingat dan memikirkan informasi atau perbedaan cara memahami, menyimpan, mentransformasi dan memanfaatkan informasi.

Ditinjau dari perbedaan aspek psikologis, gaya kognitif terdiri dari dua bagian yaitu, field dependent (FD) dan field independent (FI). Meskipun terdapat dua jenis gaya kognitif yang berbeda, tetapi tidak dapat dikatakan bahwa siswa yang memiliki gaya kognitif field dependent lebih baik dari siswa yang memiliki gaya kognitif field independent atau sebaliknya. Masingmasing siswa yang memiliki gaya kognitif field dependent atau field independent mempunyai kelebihan dalam bidangnya. Menurut Witkin dan Goodnough (Ngilawajan, 2013) individu dengan gaya kognitif field dependent adalah individu yang kurang atau tidak bisa memisahkan sesuatu bagian dari suatu kesatuan dan cenderung segera menerima bagian atau konteks yang dominan, sedangkan individu dengan gaya kognitif field independent adalah individu yang denga mudah dapat bebas dari persepsi yang terorganisir dan segera dapat memisahkan suatu bagian dari kesatuannya. Selanjutnya Witkin (Susanto, 2015) menyatakan bahwa, individu yang memiliki gaya kognitif Field Independent (FI) adalah individu yang bersifat analitik, artinya individu yang memisahkan lingkungan ke dalam komponenkomponennya, kurang bergantung pada lingkungan atau kurang dipengaruhi oleh lingkungan. Sementara individu yang memiliki gaya kognitif Field Dependent (FD) adalah individu yang bersifat global, artinya individu yang memfokuskan pada lingkungan secara keseluruhan, didominasi atau dipengaruhi lingkungan. Dengan kata lain kecendrungan gaya atau cara berpikir individu yang memiliki gaya kognitif Field Dependent (FD) dalam memahami masalah secara keseluruhan. Individu ini mengalami

kesulitan dalam membedakan stimulus melalui situasi yang dimiliki sehingga persepsinya mudah dipengaruhi oleh manipulasi dari situasi sekelilingnya. Individu yang sulit melepaskan diri dari keadaan yang mengacaukannya yaitu individu yang field dependent, akan menemukan kesulitan dalam masalahmasalah yang menuntut keterangan diluar konteks.

Proses konstruksi pengetahuan pada siswa yang memiliki gaya kognitif telah dimulai sejak dini di lingkungannya yang terus berkembang seiring pertumbuhan dan perkembangan tubuhnya sebagai suatu organisme yang utuh. Menurut teori konstruktivisme bahwa pengetahuan tidak dapat dipindahkan begitu saja dari pikiran seseorang atau guru kepada siswanya, kecuali karena keaktifan siswa itu sendiri dalam pembentukan pengetahuannya. Sedangkan Konstruktivisme menurut Vygotsky, dengan tegas Thobroni dan Mustofa (2011), menjelaskan bahwa, pengetahuan dikonstruksi secara kolaboratif antar individual dan keadaan tersebut dapat disesuaikan oleh setiap individu. Berkaitan dengan itu, berdasarkan hasil riset para ahli yang merefleksikan tentang domain pengetahuan dan peran pengalaman, serta kontek sosial dalam mengkonstruksikan dan mengembangkan pengetahuan, sebagaimana dijelaskan oleh Bereiter \& Scardamalia, 1998; Bransford, Brown, \& Cocking, 1999; Case,1998; Keil, 1998; mandler, 1998;Wellman \& Gelman, 1998; dikutip oleh Anderson \& Kratwohl, (2010) mengelompokkan pengetahuan kepada empat (4) jenis, yaitu,

1. Pengetahuan faktual, berisikan berbagai elemen dasar yang berupa simbol-simbol yang diassosiasikan dengan makna-makna konkret, serta harus di ketahui pembelajar di dalam mempelajari suatu disiplin ilmu atau untuk menyelesaikan permasalahan dalm disiplin ilmu tersebut. Pengetahuan faktual terdiri dari subjenis peengetahuan terminologi dan pengetahuan tentang detail-detail dan elemen-elemen yang spesifik.

2. Pengetahuan konseptual, mencakup tentang kategori, klasifikasi yang kompleks dan tertata, meliputi skema, model mental, atau teori yang implisit/eksplisit dalam berbagai 


\section{$\pi$ (Phi)}

model psikologi kognitif. Pengetahuan konseptual, terbagi lagi kepada 3 subjenis pengetahuan yaitu pengetahuan tentang klasifikasi dan kategori, pengetahuan tentang prinsip dan generalisasi, serta pengetahuan tentang teori, model, dan struktur.

3. Pengetahuan prosedural, yaitu pengetahuan tentang bagaimana melakukan sesuatu, baik berupa latihan rutin, masalah-masalah baru, maupun berupa rangkaian langkah yang harus diikuti seperti algoritma, teknik, dan metode yang disebut sebagai prosedur. Pengetahuan prosedural, terbagi lagi kepada 3 subjenis pengetahuan yaitu, pengetahuan tentang ketrampilan dalam bidang tertentu dan algoritma, pengetahuan tentang teknik dan metode dalam bidang tertentu, dan pengetahuan tentang kriteria untuk menentukan kapan harus menggunakan prosedur yang tepat.

4. Pengetahuan metakognitif, yaitu pengetahuan tentang kognisi secara umum dan kesadaran akan, serta pengetahuan tentang kognisi diri sendiri, kesadaran dan tanggung jawab atas pengetahuan serta pemikiran sendiri. Pengetahuan metakognitif terdiri dari pengetahuan strategis, pengetahuan tentang tugas-tugas kognitif, yang meliputi pengetahuan kontekstual dan kondisional.

Dalam menyusun pengetahuan kognitif, pembelajar field dependent memproses informasi dari lingkungannya. Kemudian merepresentasikannya di dalam pikirannya sehingga menjadi sebentuk skema-skema yang bermakna. Faktor-faktor yang mempengaruhi proses konstruksi pengetahuan, seorang ahli bernama Tasker (Yamin, 2011), mengemukakan tiga penekanan dalam teori Konstruktivistik. Pertama; peran aktif peserta didik dalam mengkonstruksi pengetahuan secara bermakna. Kedua; kemampuan membuat kaitan antara gagasan dalam pengkonstruksian secara bermakna. Ketiga; mengaitkan antara gagasan dengan informasi baru yang diterima.
Jurnal Pendidikan Matematika Volume 4 Nomor 1 Tahun 2020
Seorang anak membentuk pengetahuannya sendiri melalui proses asimilasi dan akomodasi, anak dalam lingkungannya secara aktif membentuk pengetahuannya sejak lahir dan setiap periode baru, dicirikan oleh tingkah laku yang menunjukan secara kualitatif struktur kognitif anak. Selanjutnya bagaimana seseorang membangun pengetahuan dalam dirinya sebagai seorang pembelajar, maka Mattew Olson dan Hergenhahn (2009), berdasarkan teori Piaget, menjelaskan, skema adalah istilah yang amat penting dalam teori Piaget. Suatu skema dapat dianggap sebagai elemen dalam struktur kognitif organisme. Skemata yang ada dalam organisme akan menentukan bagaimana ia akan merespons lingkungan fisik. Skemata dapat muncul dalam bentuk perilaku yang jelas, seperti dalam kasus reflek memegang, atau dapat muncul secara tersamar. Manifestasi skema yang tidak jelas dapat disamakan dengan tindakan berpikir. Jelas, cara anak menghadapi lingkungannya akan berubah-ubah seiring dengan pertumbuhan si anak. Agar terjadi interaksi organisme-lingkungan, skemata yang tersedia untuk anak harus berubah.

Skema sebagai suatu elemen dari struktur kognitif organisme akan menentukan cara seseorang merespon lingkungan fisik, muncul dalam perilaku yang jelas, atau tersamar. Manifestasi tersamar dapat dikatakan sebagai tindakan berpikir, karena setiap orang memiliki cara yang berubah-ubah menghadapi lingkungan, oleh karena itu maka skema juga berubah. Teori selanjutnya adalah Asimilasi dan Akomodasi. Sanjaya (2010) menjelaskan bahwa, asimilasi ialah penyatuan (pengintegrasian) informasi, persepsi, konsep dan pengalaman baru kedalam yang sudah ada dalam benak seseorang. Dalam proses asimilasi seseorang menggunakan struktur atau kemampuan yang sudah ada untuk menghadapi masalah yang dihadapinya dalam lingkungannya (Ratna

Proses Konstruksi Pengetahuan Siswa Ditinjau dari Gaya Kognitif Field Dependent pada Pelajaran Matematika Di SMA Negeri 8 Kota Jambi 


\section{$\pi$ (Phi)}

Wilis, 2011). Selanjutnya proses penting kedua dalam penyusunan pengetahuan intelektual (skema) seseorang setelah asimilasi adalah akomodasi, yaitu proses memodifikasi struktur kognitif. Proses penyempurnaan skema itu dinamakan proses akomodasi (Sanjaya, 2010).

Setelah membentuk skema untuk menyesuaikan pengalamannya dengan lingkungan, seseorang selanjutnya akan membentuk asimilasi yang sesuai dengan struktur kognitifnya dengan lingkungan fisiknya, sehingga pengetahuannya berkembang. Namun jika struktur kognitif tersebut berubah pada seseorang, maka seseorang tersebut akan membentuk akomodasi sebagai suatu proses modifikasi antara skema, pengetahuan, rangsangan baru.

Selanjutnya untuk memperjelas bagaimana alur proses konstruksi pengetahuan siswa maka disusunlah diagram alur tersebut, yang dimodifikasi dari teori Konstruktivisme, teori Mayer, dan Taksonomi Bloom. Adapun bagan alur proses konstruksi dijelaskan sebagai berikut.

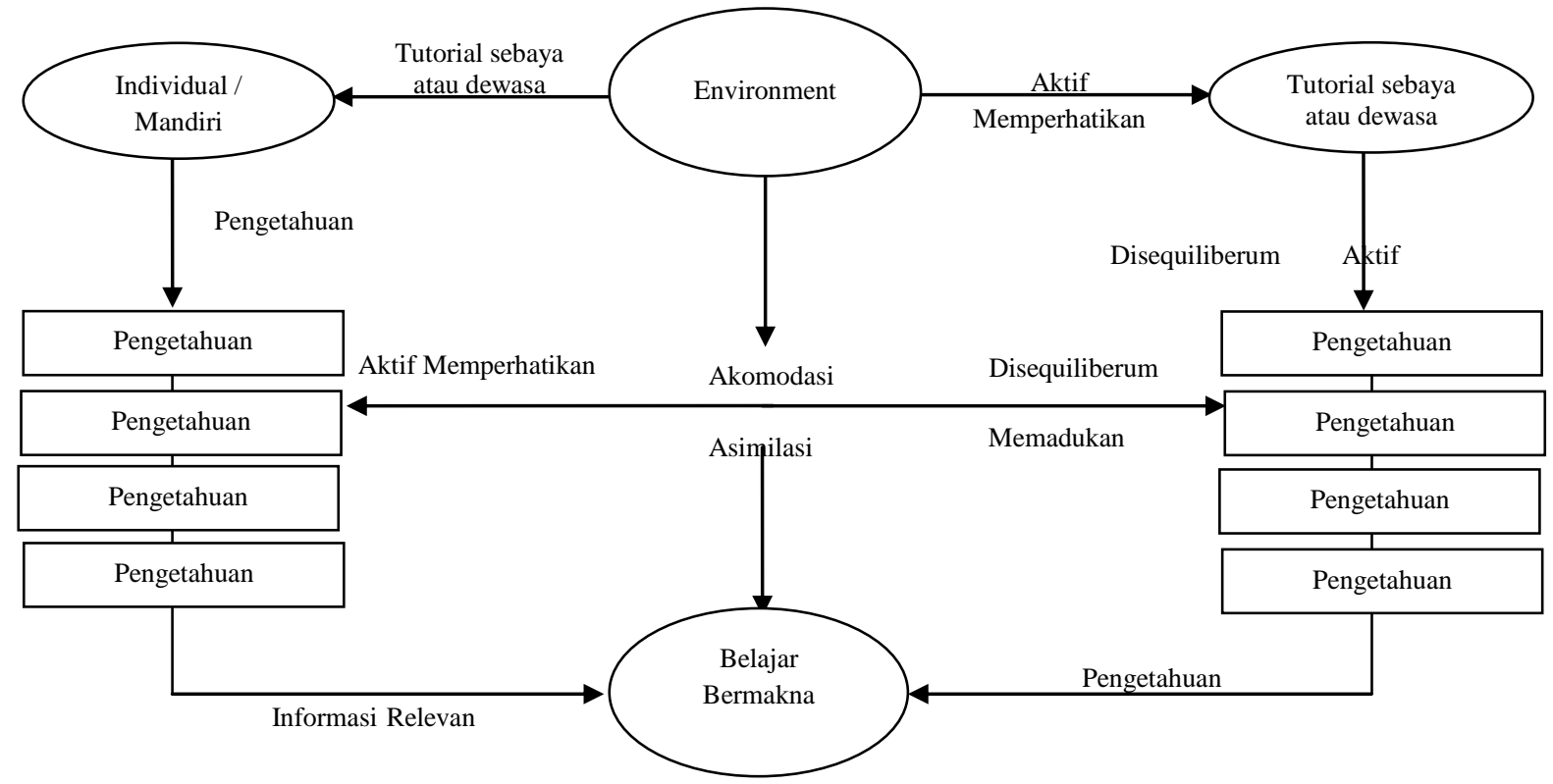

Bagan 1.1 Alur Proses Konstruksi Pengetahuan yang Dimodifikasi dari Teori Konstruktivisme, Teori Mayer, dan Taksonomi Bloom

Bagan 1.1 menjelaskan alur proses konstruksi pengetahuan pada seseorang. Alur proses tersebut berawal dari environmet yaitu lingkungan. Dari lingkungan bisa terjadi rangsangan pembelajaran baik berasal dari pembacaan, maupun dari pancaindera. Dari lingkungan tersebut, seseorang aktif memperhatikan secara mandiri/individual sehingga individu secara mandiri/dengan bantuan tutorial sebaya atau dewasa, aktif menata pengalaman apapun bentuk pengalaman itu. Keaktifan ini bisa mengakibatkan kondisi di mentalnya mengalami disequiliberum yang dapat menuju kepada pembentukan pengetahuanpengetahuan berupa: a) pengetahuan faktual, b) pengetahuan konseptual, c) pengetahuan prosedural, d) pengetahuan metakognitif. Baik secara akomodasi maupun asimilasi pada seseorang yang aktif memahami dan memadukan berbagai pengetahuan tersebut, sehingga perlahan tapi pasti tersusunlah konsep-konsep pengetahuan di dalam diri individu yang bermakna baginya, itulah belajar bermakna. Hal ini sejalan dengan pendapat Mayer (Anderson dan Kratwohl, 2010) menjelaskan bahwa belajar bermakna adalah mengkonstruksi kerangka pengetahuan.

Berdasarkan uraian diatas, maka peneliti tertarik melakukan penelitian 


\section{$\pi$ (Phi)}

tentang proses konstruksi pengetahuan siswa ditinjau dari gaya kognitif field dependent pada pelajaran matematika di SMA Negeri 8 Kota Jambi. Dengan tujuan untuk mendeskripsikan proses konstruksi pengetahuan siswa ditinjau dari gaya kognitif field dependent dalam memahami materi trigonometri pada mata pelajaran matematika di SMA Negeri 8 Kota Jambi.

\section{METODE PENELITIAN}

Penelitian ini termasuk jenis penelitian kualitatif yang menggunakan metodologi penelitian kualitatif deskriptif. Pada umumnya penelitian deskriptif dilakukan dengan tujuan utama, yaitu menggambarkan secara sistematis fakta dan karakteristik objek atau subjek yang di teliti secara tepat (Sukardi, 2012). Peneliti menggunakan jenis penelitian kualitatif deskriptif untuk menjelaskan tentang proses konstruksi pengetahuan siswa di tinjau dari gaya kognitif field dependent berdasarkan kategorikategori kognitif Taksonomi Bloom yang direvisi.

Sumber data dalam penelitian ini adalah seluruh siswa kelas X SMA Negeri 8 Kota Jambi. Subjek penelitian dalam hal ini adalah siswa yang memiliki gaya kognitif field dependent. Berdasarkan hasil tes GEFT (Group Embagged Figure Test), yang memiliki jumlah skor gaya kognitif field dependent yang tertinggilah yang diambil sebagai sampel untuk mewakili seluruh sampel siswa yang memiliki gaya kognitif field dependent, karena siswa yang memiliki skor gaya kognitif field dependent tertinggi tersebut dianggap dapat memberikan informasi mengenai tujuan penelitian yang dilakukan. Teknik pemilihan subjek penelitian yang digunakan adalah teknik snowball sampling. Menurut Sugiyono (2014), snowball sampling adalah teknik pengambilan subjek sumber data, yang pada awalnya jumlahnya sedikit, lama-lama menjadi besar. Hal ini dilakukan karena dari jumlah sumber data yang sedikit tersebut belum mampu memberikan data yang memuaskan, maka mencari subjek penelitian yang lain lagi yang dapat digunakan sebagai sumber data. Dalam sampel purposif besar, sampel atau subjek penelitian ditentukan oleh pertimbangan informasi.
Instrumen utama dalam penelitian adalah observer (peneliti sendiri). Instrumen lainnya adalah angket tes GEFT (Group Embagged Figure Test) yang dikembangkan oleh Witkin dkk, tes ini untuk pemilihan subjek penelitian, dan lembar pencerapan informasi dan deskripsi proses konstruksi pengetahuan, serta panduan wawancara yang dimaksudkan untuk membimbing peneliti di dalam mengungkap proses konstruksi siswa saat menyusun konstruksi pengetahuannya.Teknik pengumpulan data yang digunakan adalah teknik Think Aloud yang dimodifikasi dengan teknik pencerapan informasi, dan panduan wawancara untuk mengumpulkan data dari sumber informan yaitu subjek penelitian. Triangulasi data menggunakan teknik Grounded di lapangan untuk mengamati perilaku sehari-hari pada saat pembelajaran tengah berlangsung di kelas bersama guru, maupun pada saat diskusi kelompok, tugas mandiri, maupun kelompok.

\section{HASIL DAN PEMBAHASAN}

Penelitian ini bertujuan untuk mendeskripsikan proses konstruksi pengetahuan siswa ditinjau dari gaya kognitif field dependent dalam memahami materi trigonometri pada mata pelajaran matematika di SMA Negeri 8 Kota Jambi. Proses konstruksi pengetahuan siswa gaya kognitif field dependent pada pelajaran matematika melalui teknik Think Aloud pada observasi dan wawancara yang dilakukan pada subjek penelitian, dapat diungkap pada setiap observasi dan wawancara dengan subjek penelitian. Selanjutnya data hasil penelitian dianalisis berdasarkan deskripsi aktivitasaktivitas kognitif siswa dalam pembelajaran yang konstruktif berdasarkan Taksonomi Bloom yang direvisi serta dimodifikasi dengan adaptasi asimilasi dan akomodasi.

Penentuan subjek penelitian dilakukan melalui tahapan-tahapan sebagai berikut. Tahapan pertama adalah menentukan penggolongan subjek penelitian yaitu siswa gaya kognitif field dependent. Tahap selanjutnya adalah menentukan subjek yang dipilih sebagai sumber data. Berdasarkan penggolongan tersebut, serta menyesuaikan dengan kondisi dan situasi di lapangan serta situasi dan kondisi subjek penelitian, maka dari keseluruhan populasi siswa gaya kognitif field dependent 


\section{$\pi$ (Phi)}

ditetapkan dua orang subjek, dengan kriteria kedua subjek tersebut merupakan siswa yang memiliki kecenderungan gaya kognitif field dependent paling menonjol di antara seluruh populasi penelitian.

Subjek tersebut selanjutnya diberi simbol SA, untuk subjek penelitian pertama dan simbol SB untuk subjek penelitian kedua. Penentuan klasifikasi kecenderungan gaya kognitif field dependent pada siswa, ditentukan berdasarkan skor yang diperoleh pada saat SA dan SB mengisi angket berupa Group Embedded Figures Test (GEFT) terhadap SA dan SB di kelas, setelah proses pembelajaran. Berdasarkan hasil penentuan SA dan SB tersebut, maka data penelitian dapat dikumpulkan. Mengingat dan mempertimbangkan instrumen penelitian yang digunakan untuk proses observasi maka metode pengumpulan data dalam penelitian ini tidak bisa menggunakan teknik Think Aloud murni untuk mengungkapkan proses konstruksi pengetahuan pada siswa gaya kognitif field dependent akan tetapi juga menggunakan teknik wawancara untuk mengungkap proses konstruksi pengetahuan SA dan SB.

Selanjutnya data wawancara dikumpulkan dengan mengikuti petunjuk panduan wawancara yang telah divalidasi oleh ahli. Panduan wawancara ini digunakan untuk memandu peneliti tetap konsisten pada permasalahan yang sedang diteliti. Namun wawancara dapat berkembang sesuai kondisi di lapangan, akan tetapi tetap mengacu pada panduan wawancara yang telah disahkan. Untuk mengumpulkan data dari SA dan SB, digunakan instrumen lembar pencerap informasi dan panduan wawancara. Wawancara untuk mengumpulkan data pada SA dilakukan pada saat jam pelajaran sekolah tidak berlangsung. Pengumpulan data pada SB dilakukan pada hari yang sama dengan SA namun pada jam yang berbeda, yaitu setelah selesai pengambilan data pada SA. Saat wawancara dengan SA, SB tidak berada dalam ruangan wawancara. SB datang dan masuk ruangan wawancara setelah dipanggil oleh seorang siswa yang dimintai tolong untuk memanggil SB. Setelah data terkumpul dari proses konstruksi SA dan SB sebagai subjek penelitian, peneliti melakukan pengecekan keabsahan data dengan triangulasi waktu yaitu peneliti melakukan validasi terhadap data lembar pencerap informasi pertama dan kedua. Data dari

lembar pencerap informasi pertama dan data dari lembar pencerap informasi kedua pada lembar jawaban SA dan SB menunjukkan kesamaan, maka kedua data tersebut dikatakan valid.

Berdasarkan hasil wawancara dengan SA dan SB, yang terangkum dalam transkripsi wawancara yang telah dianalisis sebagai suatu data hasil dari penelitian terhadap SA dan SB yang kemudian diberi kode, dan digunakan untuk mempermudah membaca hasil penelitian. Melalui lembar pencerap informasi, serta teknik Think Aloud yang dimodifikasi dengan panduan wawancara, serta hasil wawancara, menunjukkan arti bahwa skema yang disusun oleh SA dan SB dapat dihubungkan dengan skema yang lain untuk membentuk suatu konstruksi pengetahuan. Semua proses konstruksi pengetahuan yang dibentuk oleh SA dan SB yaitu:

SA dapat mengidentifikasi dan mengetahui seluruh informasi yang dimaksud dalam lembar pencerap informasi yang telah dibacanya, dengan cepat dan langsung menjawab pertanyaan dengan benar, sehingga dapat dikatakan SA telah menyusun pengetahuannya secara asimilasi, karena pada proses ini berlangsung cepat tanpa dipikirkan terlalu lama, konstruksi pengetahuan ini terjadi dengan cara memahami dan memaknai simbol-simbol, labellabel yang sesuai dengan lembar pencerap informasi yang dibacanya. Konstruksi pengetahuan terminologi, yaitu pengetahuan tentang label atau simbol verbal dan nonverbal, termasuk jenis pengetahuan faktual. Proses konstruksi SA terhadap pengetahuan terminologi dapat diketahui melalui jawaban langsung SA terhadap pertanyaan yang dapat dijelaskan sebagai suatu konstruksi pengetahuan. Sesuai dengan penjelasan Bereiter, dkk, (Anderson \& Kratwohl, 2010), yaitu pengetahuan yang mendalam membantu siswa mengatasi permasalahan hidupnya yang nyata, sehingga menyelesaikan permasalahan pengetahuan yang lembam.

SA dapat membuat tabel atau skema, tentang materi di lembar pencerap informasi, secara langsung tanpa kesulitan, proses asimilasi. Hal ini diperkuat dengan skema yang dibuat oleh SA, sebagai berikut. Selanjutnya untuk memperkuat kualitas data tentang langkah proses konstruksi pengetahuan SA dalam wawancara, dapat dilihat melalui lembar jawaban tertulis, yaitu sketsa atau skema proses 


\section{$\pi$ (Phi)}

pemecahan masalah, yang berpadanan dengan wawancara proses konstruksi pengetahuan SA, berdasarkan panduan wawancara. SA, jelas sekali langsung dapat menyelesaikan tugasnya dengan benar, tanpa kesulitan dan tidak membutuhkan waktu lama. Ditunjukkan dengan membuat gambar/skema, mencari makna teks yang dibaca pada lembar pencerap informasi, memahami apa yang mereka dengar dari pelajaran di kelas, bahkan apapun yang mereka baca di buku maupun bahan ajar lainnya. Dalam hal ini SA langsung menyelesaikan tugas yang diajukan melalui pertanyaan panduan wawancara, sehingga peneliti dapat menentukan bahwa SA telah menyusun pengetahuannya secara asimilasi pada pengetahuan strategis. Pengetahuan strategis yaitu pengetahuanpengetahuan yang berhubungan dengan strategistrategi belajar dan berpikir serta pemecahan masalah. Sebagaimana dijelaskan oleh Weinstein dan Mayer, 1986, (Anderson \& Kratwohl, 2010), bahwa pengetahuan strategis merupakan jenis pengetahuan metakognitif. Pada pengetahuan strategis ini proses konstruksi pengetahuan SA terjadi dengan cara mengorganisasikan maknamakna teks yang terdapat pada lembar pencerap informasi.

SA mengalami disequiliberum, terlihat agak kesulitan menjawab pertanyaan, terdengar suaranya menyebutkan huruf a...yang menandakan subjek sedang berpikir, saat harus memberikan penjelasan mengenai alasan mengapa menggunakan rumus tersebut untuk pemecahan masalah, namun SA telah menyelidiki bahwa lebih mudah menggunakan rumus tersebut, segera dijawab dengan benar. Proses akomodasi. Terlihat bahwa siswa tersebut menghubungkan rencana yang telah dibuat dengan konsep/pengetahuan yang telah disebutkan sebelumnya. Oleh karena itu dapat dikatakan telah terjadi proses konstruksi pengetahuan secara akomodasi. SA mengubah pengetahuan awalnya menjadi pengetahuan baru, pada pengetahuan konseptual, sesuai dengan penjelasan Bransford, dkk, 1999, (Anderson \& Krathwohl, 2010), yang mengatakan bahwa kepakaran seseorang dapat diketahui dari kemampuannya dalam mengenali pola-pola yang bermakna (yakni generalisasi) dan mengaktifkan pengetahuan yang relevan mengenai pola-pola ini dengan sedikit upaya kognitif.

SA tampak berpikir terlebih dahulu saat diharuskan mengoreksi dan bergumam mmm...terus menjelaskan dengan benar, terlihat bahwa pada tahapan ini mengalami disequiliberum, bergumam mm...dengan penekanan nada pada gumamannya, yang menandakan sedang berpikir keras, sebelum menjawab dengan benar. Pada kondisi ini dikatakan penyusunannya adalah melalui akomodasi. Proses penyusunan pengetahuan SA pada tahap ini dilakukan dengan cara berpikir deduktif dan induktif, termasuk mengevaluasi validitas pernyataan-pernyataan yang logis, menghindari argumen-argumen yang berputarputar, membuat kesimpulan yang tepat dari berbagai sumber data, dan menunjukkan contohcontoh yang tepat untuk menarik kesimpulan berdasarkan tanda-tanda yang nyata. Pengetahuan strategis tentang analisis alat-tujuan seperti metode heuristik untuk menyelesaikan masalah pelik. Termasuk pengetahuan metakognitif, yaitu pengetahuan yang memaparkan bagaimana cara menyelesaikan masalah pelik baik menggunakan strategi umum maupun khusus. Baron dkk, (Anderson \& Kratwohl, 2010), menjelaskan bahwa berbagai startegi umum dapat menyelesaikan permasalahan dan jalan berpikir untuk permasalahan pelik yang belum ada solusi definitifnya.

Adapun hasil pembahasan alur proses konstruksi pengetahuan pada SA, telah dipaparkan, selanjutnya oleh peneliti dijelaskan dalam bentuk bagan, yang dapat dilihat pada bagan 1.2 berikut ini: 


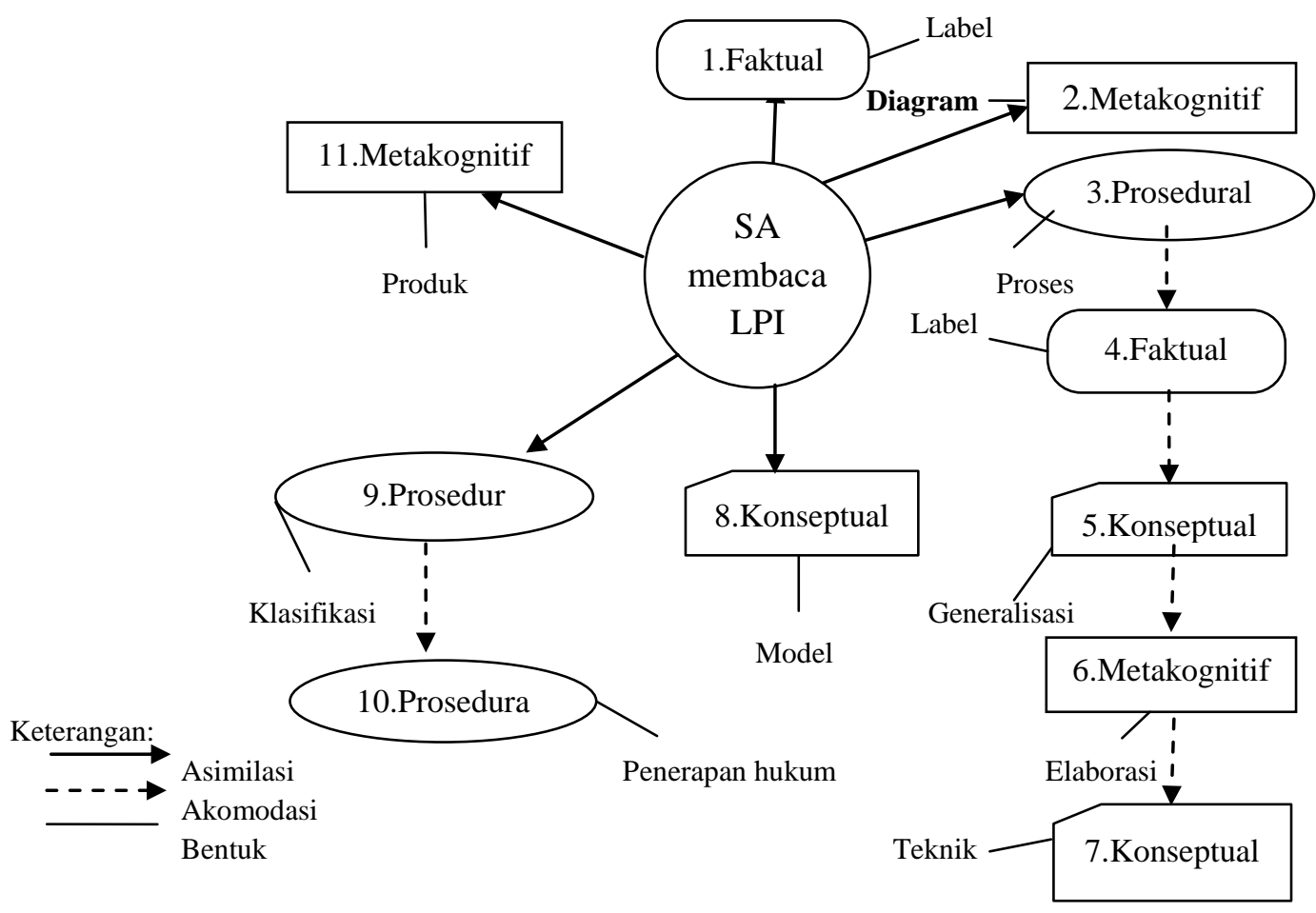

Bagan 1.2 Alur Proses Konstruksi Pengetahuan SA

Selanjutnya kontruksi pengetahuan yang dibentuk oleh SB, menunjukkan bahwa SB, bisa mengidentifikasi informasi yang dibacanya. Oleh karena itu pada kategori ini SB telah melaksanakan bentuk konstruksi pengetahuan secara asimilasi pada subjenis pengetahuan terminologi. Pengetahuan terminologi, termasuk jenis pengetahuan faktual, yaitu pengetahuan tentang label atau simbol verbal dan non verbal. Hal ini dapat diketahui melalui jawaban langsung terhadap pertanyaan, yang dapat dijelaskan sebagai suatu konstruksi pengetahuan. Pengetahuan ini merupakan label atau simbol yang menggambarkan makna untuk memahami dan memikirkan fenomena dalam suatu ilmu, sebagaimana dijelaskan oleh Bereiter dan Scardamalia, dkk, (Anderson \& Krathwohl, 2010). Proses ini berlangsung cepat tanpa dipikirkan terlalu lama, oleh karena itu, proses konstruksi pada SB tahap ini terjadi dengan cara memahami dan memaknai simbol-simbol, labellabel yang sesuai dengan lembar pencerap informasi yang dibacanya.

SB tampak langsung menyelesaikan tugas yang diajukan melalui pertanyaan panduan wawancara, sehingga peneliti dapat menentukan bahwa SB telah menyusun pengetahuannya secara asimilasi. Pada pengetahuan strategis ini
SB langsung dapat menyelesaikan tugasnya dengan benar, tanpa kesulitan dan tidak membutuhkan waktu lama. Ditunjukkan dengan membuat gambar atau skema, mencari makna teks yang dibaca pada lembar pencerap informasi, memahami apa yang mereka dengar dari pelajaran di kelas, bahkan apapun yang mereka baca di buku maupun bahan ajar lainnya. Pemahaman pengetahuan strategis, yaitu pengetahuan-pengetahuan yang berhubungan dengan strategi-strategi belajar dan berpikir serta pemecahan masalah, sesuai dengan penjelasan Weinstein dan Mayer, (Anderson \& Krathwohl, 2010). Proses konstruksi pengetahuan pada SB telah terjadi dengan cara mengorganisasikan makna-makna teks yang terdapat pada lembar pencerap informasi.

SB, pada tahapan ini terlihat yakin ketika menjawab, dan mampu langsung menjawab dengan benar. Sehingga dikatakan, SB telah menyusun pengetahuan pada tahap ini dengan cara akomodasi. SB menyesuaikan pengetahuan awalnya dengan pengetahuan baru yang diperoleh dari lingkungannya sehingga mengubah pengetahuan lamanya menjadi pengetahuan yang baru. Tahap ini disebut jenis pengetahuan prosedural, yaitu pengetahuan yang menjabarkan tentang bagaimana melakukan 
sesuatu, sesuai dengan penjelasan Alexander, dkk, juga Bransford, dkk, (Anderson \& Krathwohl, 2010) menjelaskan bahwa pengetahuan prosedural adalah pengetahuan yang menjelaskan bahwa seseorang tahu kapan dan di mana suatu prosedur tertentu harus digunakan.

SB bergumam terlihat ceria sebelum melakukan pengecekan terhadap lembar jawabannya. SB terlihat yakin dan percaya diri dengan jawabannya, sehingga proses konstruksi pengetahuannya dikatakan sebagai asimilasi. Proses konstruksi pengetahuannya terjadi dengan cara merangkum fakta-fakta dan peristiwa spesifik, mendeskripsikan proses dan interelasi di antara detail-detail dan menggambarkan proses dan interelasi di antara kategori dan klasifikasi. Sehingga bermanfaat untuk memprediksikan, menjelaskan, dan menentukan tindakan serta arahan yang harus diambil serta memeriksa kembali dari setiap peristiwa. Memeriksa terjadi ketika siswa menguji apakah suatu kesimpulan sesuai dengan premispremisnya atau tidak, apakah data-datanya mendukung atau menolak hipotesis, atau apakah suatu bahan pelajaran berisikan bagian-bagian yang saling bertentangan (Anderson dan Kratwohl, 2010).

Adapun hasil pembahasan alur proses konstruksi pengetahuan pada SB, telah dipaparkan, selanjutnya oleh peneliti dijelaskan dalam bentuk bagan, yang dapat dilihat pada bagan 1.3 berikut ini.

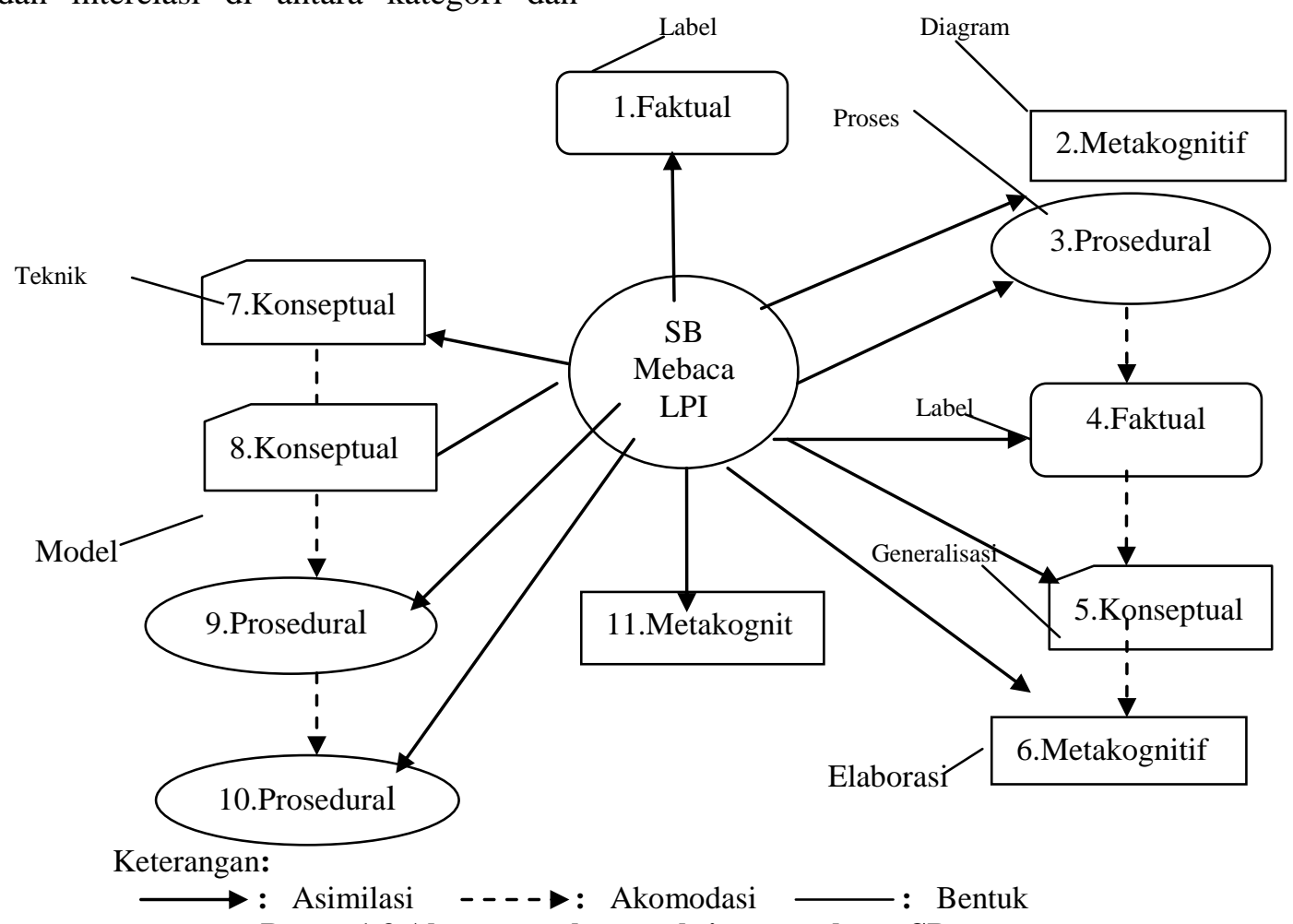

Bagan 1.3 Alur proses konstruksi pengetahuan SB

\section{SIMPULAN DAN SARAN}

Proses konstruksi pengetahuan SA dan $\mathrm{SB}$, dengan alur proses konstruksi pengetahuan yang dimodifikasi dari teori Konstruktivisme, teori Mayer, dan Taksonomi Bloom. Berawal dari environmen yaitu lingkungan, dari lingkungan bisa terjadi rangsangan pembelajaran baik berasal dari pembacaan, maupun dari pancaindera. Informasi yang dibaca melalui lembar pencerap informasi yang datang sesuai dengan skema yang dimiliki oleh SA dan SB digunakan untuk membentuk konstruksi pengetahuan selanjutnya yang sesuai dengan langkah-langkah Taksonomi Bloom yang digunakan dalam penelitian. SA dan SB menyusun pengetahuan dengan cara memahami dan memaknai simbol-simbol, label-label yang sesuai dengan fenomena lembar pencerap informasi yang dibacanya. Ini adalah pengetahuan terminologi. Terminologi termasuk 


\section{$\pi$ (Phi)}

jenis pengetahuan faktual tentang label atau simbol verbal dan nonverbal yang disusun secara asimilasi oleh SA dan SB.

SA dan SB mengkonstruksi pengetahuannya dengan cara mengorganisasikan makna-makna teks dan materi pelajaran yang terdapat pada lembar pencerap informasi. SA dan SB dengan membuat pola/skema/sketsa/peta-peta kognitif yang disebut juga peta konsep, dan secara strategis mengubah materi pelajaran ke bentuk lain untuk memahami materi secara asimilasi. Ini merupakan pengetahuan strategis, yang merupakan jenis pengetahuan metakognitif, yaitu pengetahuan-pengetahuan yang berhubungan dengan strategi-strategi belajar dan berpikir serta pemecahan masalah.

SA mengalami disequiliberum ketika menjawab pertanyaan, namun menjawab dengan benar, sehingga SA dikatakan menyusun pengetahuannya secara akomodasi. SB menyesuaikan pengetahuan awalnya dengan pengetahuan baru yang diperoleh dari lingkungannya dilakukan dengan mudah. Pengetahuan prosedural, yaitu pengetahuan yang menjelaskan tentang suatu cara tertentu untuk melakukan sesuatu, baik latihan rutin sehari-hari maupun penyelesaian masalah baru. SA dan SB, keduanya menyusun pengetahuan prosedural, dengan cara merancang suatu prosedur yang tetap dan hasilnya tepat sesuai kaidah-kaidah yang telah ditentukan, sehingga menghasilkan susunan yang benar. Proses ini terjadi dengan mudah pada pikiran kedua subjek, sehingga dapat dijelaskan bahwa ini merupakan proses asimilasi pengetahuan. adalah:

Adapun saran dalam penelitian ini

1. Bagi peneliti yang tertarik pada bidang yang sejenis ini, maka untuk melakukan suatu penelitian hendaknya dilakukan dengan apa adanya tanpa pemberian tindakan atau treatmen yang dapat mempengaruhi kualitas penelitian yang sebenarnya.

2. Penelitian jenis bidang ini masih sangat terbuka luas bagi para peneliti untuk menemukan dan mengembangkannya sehingga memperkaya bidang keilmuan ini. Bukan hanya terpaku pada gaya kognitif field dependent saja, namun bisa dikembangkan pada gaya kognitif lainnya, Diharapkan penelitian-penelitian berikutnya lebih berkembang luas serta memberi kontribusi bagi dunia pendidikan pada umumnya.

\section{DAFTAR PUSTAKA}

Desmita. (2012). Psikologi perkembangan. Bandung: Remaja Rosdakarya.

Kratwohl, R. David., \& Anderson, W. Lorin. (2010). Pembelajaran, Pengajaran, Kencana dan Assesmen. Jakarta: Pustaka Pelajar.

Mattew Olson \& Hergenhahn. (2009). Theories of learning. Jakarta: Prenada Media Group.

Ngilawajan, Darma. Andreas. (2013). Proses Berpikir Siswa Dalam Memecahkan Masalah Matematika Materi Turunan Ditinjau Dari Gaya Kognitif Field Independent Dan Field Dependent. Jurnal Pendidikan Matematika PEDAGOGIA, (2)1, 71-83.

Olson, H. Matthew., \& Hergenhahn,.R. B. (2009). Theories of Learning (Teori Belajar). Jakarta: Prenada Media Group.

Dahar, RW. (2011). Theories Belajar dan Pembelajaran, Cet. V, Jakarta: Erlangga.

Susanto, Herry. Agus. (2015). Pemahaman Pemecahan Masalah Berdasar Gaya Kognitif. Yogyakarta : Deepublish.

Sugiyono, (2014). Metode Penelitian Kuantitatif, Kualitatif \& $R \quad \& \quad D$. Bandung: Alfabeta.

Sukardi. (2012). Metodologi Penelitian Pendidikan. Jakarta: Bumi Aksara.

Thobroni dan Mustafa, (2011), Belajar dan Pembelajaran. Jogjakarta: Ar-RuzzMedia.

Wina Sanjaya. (2010). Strategi Pembelajaran Berorietnasi Standar Proses Pendidikan, Cet. VII, Jakarta: Prenada Media Group. 